\title{
Anxiolytic activity of hydro-alcohol extract of Trema guineensis and its effect on behavioral activities of mice
}

\author{
Bakou Niangoran Francois $^{1 *}$, Kpahe Ziehi Fidele ${ }^{1}$, Horo Yodanatchio Jules ${ }^{1}$, Atayi Eugene ${ }^{2}$
}

${ }^{1}$ Unit of Animal Physiology, Jean Lorougnon GUEDE University, Daloa, Cote d'Ivoire

${ }^{2}$ Neurology Service, Functional Exploration Unit of the Nervous System, C. H. U. from Cocody-Abidjan, Cote d'Ivoire

Received: 06 June 2020

Revised: 04 July 2020

Accepted: 10 July 2020

\section{*Correspondence:}

Dr. Bakou Niangoran Francois,

Email: neully2001@yahoo.fr

Copyright: (C) the author(s), publisher and licensee Medip Academy. This is an open-access article distributed under the terms of the Creative Commons Attribution Non-Commercial License, which permits unrestricted non-commercial use, distribution, and reproduction in any medium, provided the original work is properly cited.

\begin{abstract}
Background: Objective was to study the anxiolytic activity of hydro ethanolic extract of Trema guineensis.

Methods: Male swiss albino mice were used. Hydro ethanolic extract of Trema guineensis was administered in the doses of 5,10 and $20 \mathrm{mg} / \mathrm{kg}$ IP hole board (HB), open field (OF), elevated plus maze (EPM) tests were used for determination of anxiolytic activity.

Results: The hydro ethanolic extract of Trema guineensis significantly increased the number and duration of head poking in HB test. The extract also significantly increased the time spent and the number of entries in open arm in EPM. In OFT, the extract showed significant increase in number of rearing, assisted rearing and the squares crossed. Conclusions: In the present study, Trema guineensis exhibited anxiolytic activity which might be attributed to its phytoconstituents like alkaloid, steroid and triterpenes. Since Trema guineensis is ubiquitous and abundantly grown, it could be a fairly economical therapeutic agent for management of anxiety disorders.
\end{abstract}

Keywords: Trema guineensis, Anxiety, Mice

\section{INTRODUCTION}

Anxiety-related disorders such as generalized anxiety, panic, obsessive-compulsive disorder, phobias or posttraumatic stress are the most common mental illness and a major cause of disability in the world. ${ }^{1}$ Anxiety disorders are among the most common psychiatric disorders that affect all age groups of the general population. ${ }^{2}$ Approximately 450 million people suffer from a mental or behavioral disorder. ${ }^{3}$ Although benzodiazepines are among the first line of anxiolytic drugs with well-known benefits, their side effects are prominent, including sedation, muscle relaxation, anterograde amnesia and physical dependence. Therefore, finding novel therapeutic agents with fewer complications in the treatment of anxiety disorder, is of major interest to researchers. ${ }^{4}$ Despite a phenomenal development of modern drug industry, medicinal plants with traditional background of use in neurological diseases could be good candidates to find new anxiolytic agents. Plants of the Trema guineensis, from Ulmaceae family are among important medicinal plants in Ivorian traditional medicine. They have long been used in the treatment of health problems and diseases. Trema guineensis leaves are empirically used for sore throat, cough and hypertension treatment. ${ }^{5}$ Literature survey revealed a variety of pharmacological actions such as anticonvulsant, analgesic, anti-inflammatory, antiplasmodial activities for these plants. ${ }^{6-8}$ Its phytochemical analysis indicated the presence of several secondary metabolites such as polyphenols, alkaloids, flavonoids, saponosids and tannins. The presence of these compounds could confer to the plant, these several 
pharmacological activities. No scientific report regarding the in vivo anxiolytic activity of Trema guineensis extract (TG) has been published. That's why, the present study was undertaken to assess the possible anxiolytic effects following single administration of hydro ethanolic extract of leaves from Trema guineensis in mice. For this purpose, we used the elevated plus-maze, hole board and open field tests.

\section{METHODS}

\section{Plant material}

Fresh leaves of the plant were collected from Daloa, Cote d'Ivoire in October, 2019. The plant was identified and verified by botanist Professor from Jean Lorougnon GUEDE university of Daloa, Cote d'ivoire. The collected leaves were dried under a shade during two weeks and pulverized using the crushing assistance (IKAMAG RCT®). The powder of leaves obtained, constituted our sample to be analyzed.

\section{Extract preparation}

$100 \mathrm{~g}$ of Trema guineensis powder were extracted in one liter $(1 \mathrm{ltr})$ of ethanol-water mixture $(70 / 30 \mathrm{v} / \mathrm{v})$. The mixture obtained was then homogenized using a mixer during 24 hours. The homogenate obtained is filtered successively twice on absorbent cotton then once on Wattman No. 1 filter paper. The filtrate was carried thereafter to evaporation in a drying oven with $50^{\circ} \mathrm{C}$ during 48 hours.

\section{Animals}

Healthy adult male swiss albino mice weighing (20-30 g) were obtained from the animal house of Jean Lorougnon GUEDE University, Daloa. These animals were housed under standard environmental conditions. The mice were fed with FACI ${ }^{\circledR}$ (Fabrication d'Aliments de Cote d'Ivoire) pellets, groundnuts and dried fish. They had free access to drinking water ad libitum.

\section{Drugs and chemicals}

The standard drugs diazepam was collected from square pharmaceuticals ltd., Cote d'Ivoire. Saline water which was used for dilution purpose was prepared was obtained from Jean Lorougnon GUEDE university of Daloa (Cote d'ivoire).

\section{Behavioral parameters used to test anxiolytic activity elevated plus-maze test}

The elevated plus-maze (EPM) test consisted of two open arms $(30 \times 5 \times 0.25 \mathrm{~cm})$ and two closed arms $(30 \times 5 \times 15 \mathrm{~cm})$ emanating from a common central platform $(5 \times 5 \mathrm{~cm})$. Two pairs of identical arms were opposite to each other. The entire apparatus was elevated to a height of $40 \mathrm{~cm}$ above floor level. At the beginning of the session, a mouse was placed at the centre of the maze, its head facing an open arm and allowed to explore the maze for 5 minutes, and the following parameters were scored: the time spent and number of entries in each type of arms. ${ }^{9}$ The plus maze was carefully cleaned with a wet towel after each animal test. The mice were divided into five groups (5 mice/group). The control group received vehicle (saline water $0.1 \mathrm{ml} / \mathrm{mice})$. Diazepam $(1 \mathrm{mg} / \mathrm{kg}$ BW, IP) was used as the positive control or standard group and Trema guineensis extract at doses of 5, 10 and $20 \mathrm{mg} / \mathrm{kg}$ body weight, in the three remaining groups. After each trial, the EPM apparatus was wiped clean with alcohol $70 \%$ solution.

\section{Open field test}

Locomotor activity and exploratory behavior were assessed in an open field. The apparatus consisted of a wooden box $\left(60 \times 60 \times 30 \mathrm{~cm}^{3}\right)$ with the floor divided into 16 squares $\left(15 \times 15 \mathrm{~cm}^{2}\right)$. The apparatus was illuminated with a 40-W lamp suspended $100 \mathrm{~cm}$ above. Mice were treated with Trema guineensis (5,10 and $20 \mathrm{mg} / \mathrm{kg}$, i.p.), diazepam $(1 \mathrm{mg} / \mathrm{kg}$, IP) was used as the positive control drug or vehicle (IP). After 30 minutes, they were placed individually in one of the corner squares. The number of rearing, assisted rearing (forepaws touching the wall of the apparatus) and squares traveled were counted for 5 minutes. ${ }^{10}$

\section{Hole board test}

The hole board apparatus consisted of a wooden chamber $\left(40 \times 40 \times 25 \mathrm{~cm}^{3}\right)$ with 16 holes (each of $3 \mathrm{~cm}$ diameter) evenly distributed on the floor. The apparatus was elevated to a height of $25 \mathrm{~cm}$ from the ground so that the mice could peep through the holes. The mice were treated with Trema guineensis (5, 10 and $20 \mathrm{mg} / \mathrm{kg}$, IP), diazepam $(1 \mathrm{mg} / \mathrm{kg}$, IP) or distilled water (IP) 30 minutes prior to test and kept in the apparatus. The numbers and the duration of head poking were recorded during the 5 minutes observation period

\section{Statistical analysis}

Results are expressed as mean \pm SEM. The statistical analysis of data was done using the one-way analysis of variance (ANOVA) followed by Dunnett's test. A probability level less than 0.05 was considered statistically significant.

\section{RESULTS}

\section{Elevated plus maze test}

The saline-treated mice spent $28.8 \pm 1.2 \mathrm{~s}$ in the open arm and $247 \pm 2.6 \mathrm{~s}$ in the closed arm, with $9.3 \pm 4.5$ entries into the open arm and 11.7 \pm 2.6 entries into the closed arm. Trema guineensis (5 and $10 \mathrm{mg} / \mathrm{kg}$ ) and diazepam (1 $\mathrm{mg} / \mathrm{kg})$ induced significant $(\mathrm{p}<0.01)$ increase in the occupancy in the open arm. 
Table 1: Effect of Trema guineensis on animals' stay in the open and enclosed arms of the elevated plus-maze in mice $(\mathbf{n}=5)$.

\begin{tabular}{|c|c|c|c|c|}
\hline Treatment & $\begin{array}{l}\text { Time spent in the open } \\
\operatorname{arm}(\mathrm{s})\end{array}$ & $\begin{array}{l}\text { Time spent in the } \\
\text { enclosed arm (s) }\end{array}$ & Entries into open arm & $\begin{array}{l}\text { Entries into } \\
\text { enclosed arm }\end{array}$ \\
\hline NaCl 10 ml & $28.8 \pm 1.2$ & $247 \pm 2.6$ & $9.3 \pm 4.5$ & $11.7 \pm 2.6$ \\
\hline DZP 1 mg/kg & $104 \pm 6.4 * *$ & $159 \pm 4.5^{* *}$ & $20.5 \pm 1.9 * *$ & $8.7 \pm 1$ \\
\hline RV5 mg/kg & $115 \pm 1.2 * *$ & $138.2 \pm 2.4 * *$ & $18.5 \pm 1.7 * *$ & $9.5 \pm 2.1$ \\
\hline RV10 mg/kg & $90.8 \pm 12 * *$ & $219.8 \pm 1.8$ & $8.3 \pm 4.1$ & $10.5 \pm 2.4$ \\
\hline RV20 mg/kg & $30.5 \pm 2.6$ & $220.7 \pm 2.1$ & $10.2 \pm 4.2$ & $9.7 \pm 2.2$ \\
\hline
\end{tabular}

Values are expressed as mean \pm SEM. $*-p<0.05, * *-p<0.01$

Table 2: Effect of Trema guineensis on rearing and locomotion in open field test model (n=5).

\begin{tabular}{|llll|}
\hline Treatment & Rearing & Assisted rearing & Number of square traversed \\
\hline NaCl 10 ml & $3.5 \pm 1.2$ & $10.8 \pm 1.2$ & $85.2 \pm 1$ \\
\hline DZP $1 \mathbf{~ m g / k g}$ & $14 \pm 6.4^{* *}$ & $20.7 \pm 6.4^{* *}$ & $154 \pm 3.4^{* *}$ \\
\hline RV5 $\mathbf{~ m g / k g}$ & $29.5 \pm 2.6^{* *}$ & $19.5 \pm 2.6^{*}$ & $115.2 \pm 1.2^{* *}$ \\
\hline RV10 $\mathbf{~ m g / k g}$ & $20.8 \pm 5.2^{* *}$ & $18.8 \pm 2.2^{*}$ & $135.8 \pm 2.2^{* *}$ \\
\hline RV20 $\mathbf{~ m g / k g ~}$ & $11 \pm 2.2$ & $12.3 \pm 1.2$ & $147.5 \pm 2.6^{* *}$ \\
\hline
\end{tabular}

Values are expressed as mean \pm SEM. * $-\mathrm{p}<0.05, * *-\mathrm{p}<0.01$

Trema guineensis in the dose of 10 and $20 \mathrm{mg} / \mathrm{kg}$ did not cause a significant decrease in the time spent in the closed arm, whereas Trema guineensis at a dose of 5 $\mathrm{mg} / \mathrm{kg}$ and diazepam brought about a significant $(\mathrm{p}<0.01)$ decrease in the time spent in the closed arm. The animals treated with diazepam and Trema guineensis $(5 \mathrm{mg} / \mathrm{kg})$ showed a decreased preference for the closed arm and significantly $(\mathrm{p}<0.01)$ increased entries into the open arm. Trema guineensis at 10 and $20 \mathrm{mg} / \mathrm{kg}$ did not produce any significant increase in open arm entries (Table 1).

\section{Open field test}

The salne-treated mice traversed $85.2 \pm 1$ square and showed $10.8 \pm 1.2$ assisted rearing and $3.5 \pm 1.2$ self-rearing during the test interval of 5 minutes. Trema guineensis at 5 and $10 \mathrm{mg} / \mathrm{kg}$ and diazepam brought about a significant $(p<0.01)$ and dose-dependent increase in the number of squares traversed. The assisted rearing and self-rearing were significantly $(\mathrm{p}<0.05$ and $\mathrm{p}<0.01$, respectively) increased by Trema guineensis ( 5 and $10 \mathrm{mg} / \mathrm{kg}$ ) and diazepam; Trema guineensis at $20 \mathrm{mg} / \mathrm{kg}$ did not a produce significant effect (Table 2).

\section{Hole board test}

Each mouse was placed individually in the hole-board apparatus and the number of head pokes and the duration of head poking were noted. With the dose of $20 \mathrm{mg} / \mathrm{kg}$, IP, of Trema guineensis there was no significant increase in number of head pokes when compared with vehicle. Trema guineensis at 5 and $10 \mathrm{mg} / \mathrm{kg}$, IP, increased the number of head pokes significantly $(\mathrm{p}<0.01)$ and dose dependently. The duration of head poking was also significantly $(\mathrm{p}<0.01)$ increased by Trema guineensis at all doses.
The reference standard (diazepam, $1 \mathrm{mg} / \mathrm{kg}$, IP) treated group showed significant increase in exploratory activity $(\mathrm{p}<0.01)$ (Table 3).

Table 3: Effect of Trema guineensis on hole board $(\mathbf{n}=5)$.

\begin{tabular}{|lll|}
\hline Treatment & $\begin{array}{l}\text { Duration on head } \\
\text { poking }(\mathbf{s})\end{array}$ & $\begin{array}{l}\text { Number of head } \\
\text { poking }\end{array}$ \\
\hline NaCl 10 ml & $28.8 \pm 1.2$ & $26.8 \pm 1.2$ \\
\hline $\begin{array}{l}\text { DZP } \\
\mathbf{1 ~} \mathbf{~ m g} / \mathbf{k g}\end{array}$ & $70 \pm 6.4 * *$ & $74 \pm 6.4 * *$ \\
\hline $\mathbf{R V 5} \mathbf{~ m g / k g}$ & $50 \pm 1.2 * *$ & $48 \pm 1.2 * *$ \\
\hline $\mathbf{R V 1 0} \mathbf{~ m g / k g}$ & $74.8 \pm 12 * *$ & $76.8 \pm 12 * *$ \\
\hline RV20 $\mathbf{~ m g / k g}$ & $90.5 \pm 2.6 * *$ & $27.1 \pm 2.6$ \\
\hline \multicolumn{2}{|l|}{ Values are expressed as mean \pm SEM. $*-\mathrm{p}<0.05, * *-\mathrm{p}<0.01$} \\
\hline
\end{tabular}

\section{DISCUSSION}

The benzodiazepines (BZDs) are relatively safe and are widely used anxiolytic agents. These agents are known to act through the BZD-GABA receptors. The role of GABA in anxiety is well established. ${ }^{11}$ The EPM is one of most popular animal tests for research on behavioral pharmacology of anxiety. It involves spontaneous or natural aversive stimuli, i.e., height, unprotected opening, and novelty. ${ }^{12}$ Several plants that are used in folk medicine to diminish anxiety are reported to bring about an increase in the exploration of the open arms in the EPM test. ${ }^{13}$ In EPM, NAOVE mice will normally prefer to spend much of their allotted time in the closed arms. This preference appears to reflect an aversion towards open arms that is generated by fear of open spaces. Drugs that increase open arm exploration are considered as anxiolytics and the reverse holds true for anxiogenics. ${ }^{14}$ In our study, we noticed that Trema guineensis ( 5 and 10 $\mathrm{mg} / \mathrm{kg}$ ) induced significant increases in the both the 
number of entries and time spent in the open arms. The number of entries and the time spent in the closed arms were reduced in the extract-treated group as compared to the control group. The open-field apparatus provides information on anxiety-related behavior characterized by natural aversion of rodents to an open brightly lit area. ${ }^{15}$ Animals are thus afraid of the centre and spend more time in the protective corners and in freezing state. Anxiolytics increase total locomotive activity resulting in a reduction of time spent in corners, an increased time spent in the center and a decreased time spent in freezing state. The results obtained in the open field test showed that Trema guineensis administration significantly increased rearing, assisted rearing, and number of squares traversed, which supports the anxiolytic-like activity of Trema guineensis. The anxiolytic activity of some agents has been assessed by using the hole-board test. ${ }^{16} \mathrm{~A}$ significant increase in the exploratory head-dipping behavior was observed after treatment with 5 and $10 \mathrm{mg} / \mathrm{kg}$ of Trema guineensis extract, thus reinforcing the hypothesis that it has anxiolytic-like activity. These results confirm the anxiolytic effects of Trema guineensis. They are to be compared with the work of Nsour, who in a similar study showed the anxiolytic effect of Rauvolfia serpentina; from Aidee who highlighted the anxiolytic effects of the ethanolic extracts of Argemone mexicana; from Carla et al who demonstrated anxiolytic properties of aqueous extracts of Salvia miltiorrhiza in rats; Charles and Carnevale, who showed anxiolytic properties of extracts of Maerua angolensis in mice and Griffonia simplicifolia in rat. ${ }^{17-21}$ The anxiolytic effect of the hydro ethanolic leaves from Trema guineensis could be due to the presence of alkaloids among the compounds of Trema guineensis. Indeed, Aidee demonstrated that the alkaloids isolated from Argemone mexicana extracts increased the percentage of time spent in the open arms of rat EPM, in the same way as diazepam and Argemone mexicana extracts. $^{18}$

\section{CONCLUSION}

In conclusion, the results obtained in our study suggest that the extract of the leaves of Trema guineensis possesses anxiolytic activity, which is possibly mediated through the GABA A-BZD mechanism. Thus, Trema guineensis has potential clinical application in the management of anxiety disorders. Further investigation of the mechanisms of action of the plant extract, as well as the active substances responsible for its biological actions, is necessary.

Funding: No funding sources Conflict of interest: None declared

Ethical approval: The study was approved by the Institutional Ethics Committee

\section{REFERENCES}

1. Chandana CB, Archana T, Shameem AB. Indian J Pharmacol. 2012;44(1):63-7.
2. Kessler RC, Angermeyer M, Anthony JC. Life time prevalence and age-of-onset distributions of mental disorders in the World Health Organization's World Mental Health Survey initiative. World Psychiatry. 2007;6:168-76.

3. World Health Report. Mental health: New understanding new hope. WHO, Geneva? 2001.

4. Kent JM, Mathew SJ, Gorman JM. Molecular targets in the treatment of anxiety. Biol Psychiatry. 2002;52:1008-30.

5. Gnaoue G. Evaluation de 1' activite physiologique et biochimique de Landolphia Hirsuta et de Trema guineen-sis sur le systeme cardio-vasculaire et sur l'activite contractile du duodenum de mammiferes. Thesis, Cocody University, Abidjan; 2009.

6. Panchal HS, Master SM, Shah UD. Anti-convulsion activity of leaf of Trema orientalis. Int J Pharm Res. 2010;2:53-5.

7. Barbera R, Trovato A, Rapisarda A. Analgesic and anti-inflammatory activity in acute and chronic conditions of Trema guineense (Schum et Thonn.) ficalho and trema micrantha blume extracts in rodents. Phytother Res. 1992;6:146-8.

8. Abiodun O, Gbotosho G, Ajaiyeoba E. In vitro antiplasmodial activity and toxicity assessment of some plants from Nigerian ethnomedicine. Pharm Biol. 2011;49:9-14.

9. Pellow S, Chopin P, File SE, Briley M. Validation of open: closed arm entries in an elevated plus-maze as a measure of anxiety in the rat. J Neurosci Methods. 1985;14:149-67.

10. Garcia GAG, Contreras CM. Stressors can affect immobility time and response to imipramine in the rat forced swim test. Pharmacol Biochem Behav. 2009;91:542-8.

11. Rang HP, Dale MM, Ritter JN. Pharmacology: Churchill Livingstone; 2003: 483-494.

12. Dhonnchadha BA, Bourin M, Hascoet M. Anxiolyticlike effects of 5-HT 2 ligands on three mouse models of anxiety. Behav Brain Res. 2003;140:203-14.

13. Thakur VD, Mengi SA. Neuropharmacological profile of Eclipta Alba L. Hassk. J Ethnopharmacol. 2005;102:23-31.

14. Ibarrola HMC, Ibarrola DA, Montalbetti Y. The anxiolytic-like effects of Aloysia polystachya (Griseb) Moldenke (Verbenaceae) in mice. J Ethnopharmacol. 2006;105:400-8.

15. Choleris E, Thomas AW, Kavaliers. A detailed ethological analysis of the mouse open field test: Effects of diazepam, chlordiazepoxide and an extremely low frequency pulsed magnetic field. Neurosci Behav Rev. 2001;25:235-60.

16. Bhatacharya SK, Satyan KS. Experimental methods for evaluation of psychotropic agents in rodents: Anti-anxiety agents. Indian J Exp Biol. 1997;35:56575.

17. Nsour WM, Lau CB, Wong IC. Review on phytotherapy in epilepsy Seizure. 2001;9:96-107.

18. Aidee IA, Omar DM, Miguel AD. Anxiolytic-like effect of ethanolic extract of Argemone mexicana and 
its alkaloids in Wistar rats. Avicenna J Phytomed. 2016;6:476-88.

19. Carla L, Giancarlo C, Gian LG. Anxiolytic effect of an extract of Salvia miltiorrhiza roots in rats. JCMA. 2018;81:390-7.

20. Charles KB, Robert PB, Donatus WA. Anxiolytic and Anti-depressant Effects of Maerua angolensis DC; Stem Bark Extract in Mice. Depress Res Treat. 2018;5:1-17.
21. Carnevale G, Viesti DV, Zavatti M. Anxiolytic like effet of Griffonia simplicifolia Baill; Seed extract in rats. Phytomedicine. $2011 ; 18(10): 848-51$.

Cite this article as: Francois BN, Fidele KZ, Jules HY, Eugene A. Anxiolytic activity of hydro-alcohol extract of Trema guineensis and its effect on behavioral activities of mice. Int J Basic Clin Pharmacol 2020;9:1186-90. 